\title{
The Effect of Essential Oil Intake on Changes of Plasma Antioxidant Status in Mice
}

\author{
Š. FAIX ${ }^{1}$, S̆. JUHAS ${ }^{1}$, Z. FAIXOVÁ ${ }^{2}$ \\ ${ }^{1}$ Institute of Animal Physiology, Slovak Academy of Sciences, Košice, Slovak Republic \\ ${ }^{2}$ University of Veterinary Medicine, Košice, Slovak Republic \\ Received February 1, 2007 \\ Accepted July 9, 2007
}

\begin{abstract}
Faix ড̌s., Š. Juhas, Z. Faixová: The Effect of Essential Oil Intake on Changes of Plasma Antioxidant Status in Mice. Acta Vet. Brno 2007, 76: 357-361.

The aim of this study was to determine the effects of four essential oils intake by feed, namely Origanum vulgare, Thymus vulgaris, Cinnamomum zeylanicum Ness, and Syzygium aromaticum on antioxidant status in mice in vivo. Essential oils were in the aether oleum form. They were diluted with ethanol absolute mixed with ground pelett $(0.1,0.25,0.57$ and $1 \%$ concentration) and thereafter ethanol was evaporated. SOD, GPx activities and TAS were measured in erythrocytes and plasma spectrophotometrically with Ransod, Ransel and TAS kits from RANDOX, respectively. GPX activity showed a significant increase in $0.25 \%$ and $0.1 \%$ concentration of Origani aetheroleum. The GPx activities were decreased in 1\% concentration of Thymi aetheroleum and $0.57 \%$ concentration of Cinnamomi aetheroleum and $0.57 \%$ concentration of Caryophylli aetheroleum. The total antioxidant status showed a significant decrease in $1 \%$ concentration of Origani aetheroleum and significantly increased in $0.1 \%$ concentration. The same results were found in Thymi aetheroleum. Cinnamomi aetheroleum and Caryophylli aetheroleum had not effect on total antioxidant status. SOD activities were not significantly changed after intake of essential oils. In conclusion, our results showed, that concentration of essential oil is very important for antioxidant status and also for metabolism of mice, because a high dose of essential oil has adverse effect on metabolism of mice, representated by a lower growth of the body weight. On the other hand, essential oils at lower concentrations have positive effect on antioxidant status of mice.
\end{abstract}

Antioxidant activity, vegetable essence, GPx, SOD, TAS

Antioxidant systems are being shown to play an increasing role in the protection against exogenous oxidative stress. Many authors have reported antimicrobial, antifungal, antioxidant and radical-scavenging properties by spices and essential oils and, in some cases, a direct food-related application has been tested (Madsen and Bertelsen 1995; Sawamura 2000; Horosova et al. 2004; Hsu and Liu 2004a; Masella et al. 2004; Sacchetti et al. 2005). Spices and herbs are recognized as sources of natural antioxidants and thus play an important role in the chemoprevention of diseases. Exposure to oxidant molecules released from the environment, nutrition or pathologies can generate reactive oxygen species (Faix et al. 2005). Cells have developed enzymatic systems that convert oxidants into non-toxic molecules, thus protecting the organism from the deleterious effects of oxidative stress. SOD is the first line in cell defense against oxidative stress. It converts the superoxide anion $\mathrm{O}_{2}$ - into a less toxic product, namely $\mathrm{H}_{2} \mathrm{O}_{2}$ and $\mathrm{O}_{2}$ (McCrod et al. 1976). In $\mathrm{H}_{2} \mathrm{O}_{2}$ detoxification, the selenium dependent glutathione peroxidase (GSHPx) converts $\mathrm{H}_{2} \mathrm{O}_{2}$ into water via the oxidation of reduced glutathione (GSH) in oxidized glutathione (GSSG) (Bruce et al. 1982).

The extracts from Origanum vulgare, Thymus vulgaris, Cinnamomum zeylanicum Ness and Syzygium aromaticum were evaluated for the possible mode of action by studying their antioxidant potential.

\section{Materials and Methods}

During the whole study, the principles of the Ethical committee for the protection of animals in research of the Institute were strictly followed.

Address for correspondence:

Doc. MVDr. Štefan Faix PhD

Institute of Animal Physiology

Slovak Academy of Sciences

Šoltesovej 4-6

04001 Košice, Slovak Republic
Phone:++421556336268

Fax: ++421556332048

e-mail: faix@saske.sk

http://www.vfu.cz/acta-vet/actavet.htm 

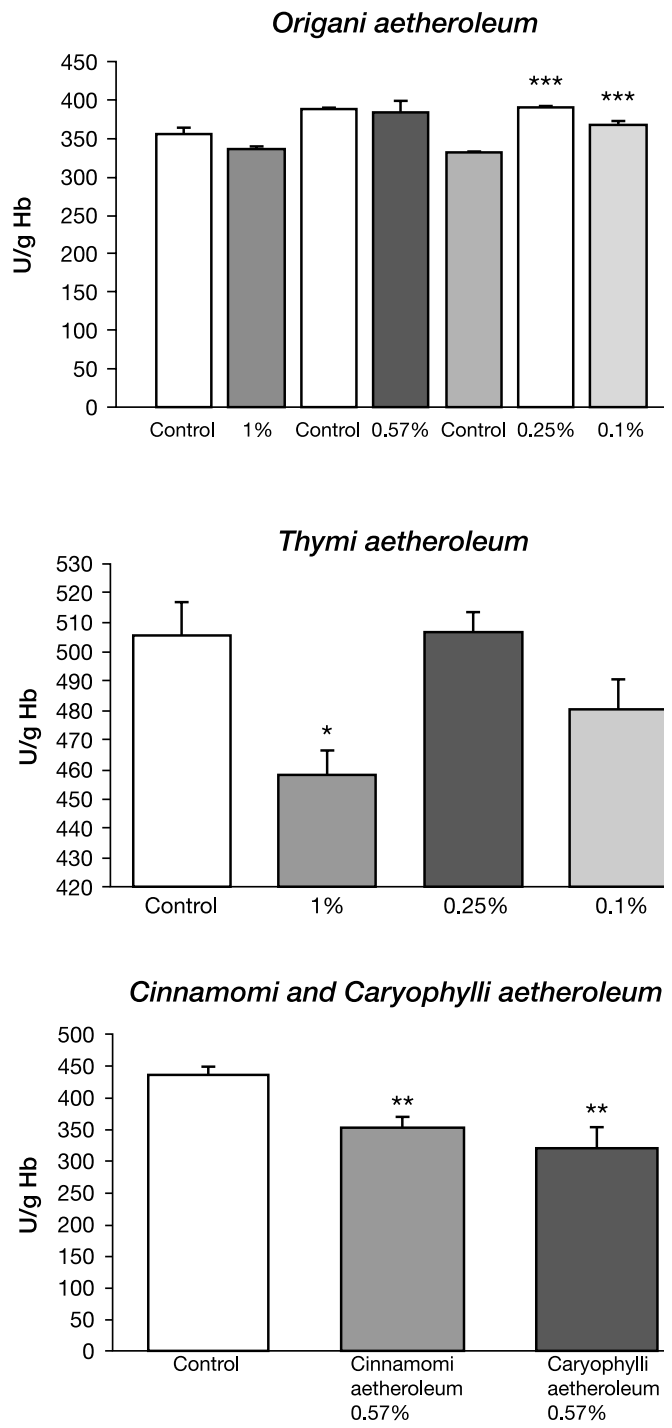

Fig. 1. GPx concentration in blood of mice. Each value represents the mean \pm S.E.M.; $\mathrm{n}=10\left({ }^{*} P<0.05\right.$, $* * P<0.01, * * * P<0.001)$
Four essential oils, namely Origanum vulgare, Thymus vulgaris, Cinnamomum zeylanicum Ness and Syzygium aromaticum were obtained from CALENDULA a.s. (Nová Lubovňa, Slovak Republic). Ransod, Ransel and TAS kits were obtained from RANDOX Laboratories Ltd, UK.

Male mice (ICR bred), 5-6 weeks of age, were used in the present study. The mice were housed at $22{ }^{\circ} \mathrm{C}$ with a $12: 12$-h dark-light cycle $(5.00-17.00$ hours lights on). They were maintained on a standard pellet diet for mice with tap water ad libitum. Each group contained 10 mice. The control groups were given standard diet for 20 days. Experimental groups were fed standard diet plus supplementation of different essential oils. Essential oils were in aether oleum form. They were diluted with ethanol absolute mixed with ground pellet and thereafter ethanol was evaporated. Final content concentration was different for each essential oil. The final contents of Origani aetheroleum were $1 \%, 0.57 \%, 0.25 \%$ and $0.1 \%$. The final contents of Thymi aetheroleum were 1\%, $0.25 \%$ and $0.1 \%$. Cinnamomi aetheroleum and Caryophylli aetheroleum were used at $0.57 \%$ concentration only. Mice were removed from their cage and rapidly decapitated by guillotine. Blood samples were collected into tubes containing heparin. For SOD determinations, erythrocytes were obtained from $1 \mathrm{ml}$ of blood by centrifugation at $805 \mathrm{~g}$ for 10 minutes, at room temperature, immediately after the blood was drawn; they were washed three times in a $0.9 \mathrm{~mol}$ $\mathrm{NaCl}$ solution and stored at $-70^{\circ} \mathrm{C}$ until analysis. For GPx activity assays, fresh whole blood was collected and stored at $-70^{\circ} \mathrm{C}$. Samples were haemolysed by the addition of ice cold distilled water (1/10), cell membranes were removed by centrifugation, and the supernatant was used for the analysis.

SOD (EC 1.15.1.1) and GPx (EC 1.11.1.9) activities were assayed in erythrocytes spectrophotometrically with Ransod and Ransel kits, respectively, using a UVVIS spectrophotometer. SOD activity was expressed as the amount of protein causing a $50 \%$ inhibition of formazan dye (505 nm), employing xanthine and xanthine oxidase to generate superoxide radicals. Units of GPx activity were calculated following NADPH oxidation at $340 \mathrm{~nm}$ using cumene hydroperoxide as the substrate. Total antioxidant status was measured in blood plasma by incubation of ABTS with a peroxidase (metmyoglobin) and hydrogen peroxide in the production of the radical cation ABTS + . This species is blue-green in colour and can be detected at $600 \mathrm{~nm}$.

Data are expressed as mean \pm (S.E.M.). The comparison between values was performed by unpaired Student's $t$-test.

\section{Results and Discussion}

The present study evaluated the effects of feeding diets with essential oils contents on oxidative stress in mice. As shown in Fig. 1, GPx activity showed a significant increase in $0.25 \%$ and $0.1 \%$ concentration of Origani aetheroleum (388.7 \pm 2.7 and $366.1 \pm 4.6 \mathrm{vs} 329.5 \pm 1.6 \mathrm{U} \cdot \mathrm{g}^{-1} \mathrm{Hb}, P$ $<0.001)$. The GPX activities were decreased in $1 \%$ concentration of Thymi aetheroleum $(457.7$ \pm 8.7 vs $505.2 \pm 11.8 \mathrm{U} \cdot \mathrm{g}^{-1} \mathrm{Hb}, P<0.05$ ) and $0.57 \%$ concentration of Cinnamomi aetheroleum

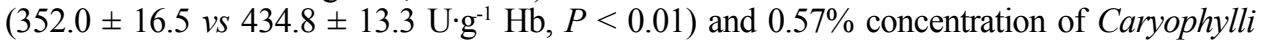




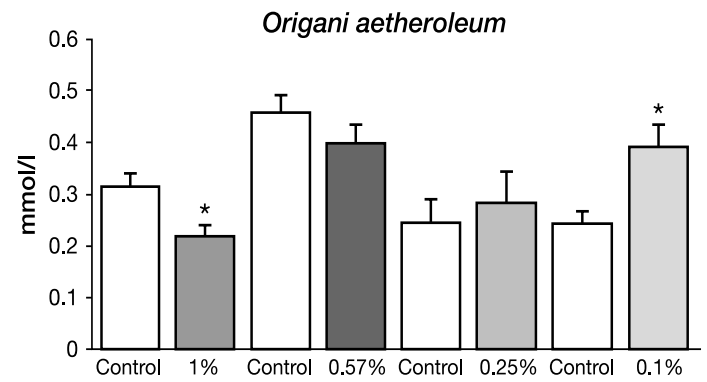

Thymi aetheroleum

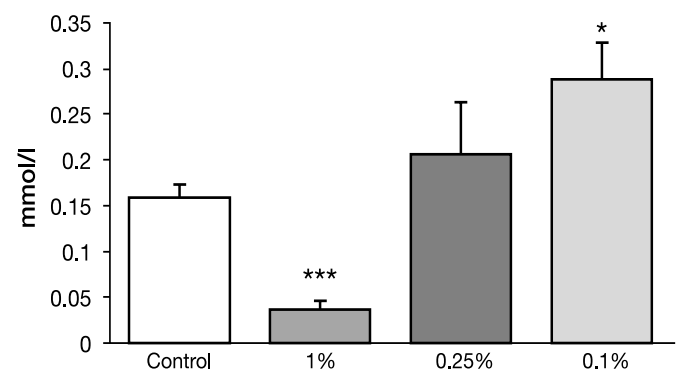

Cinnamomi and Caryophylli aetheroleum

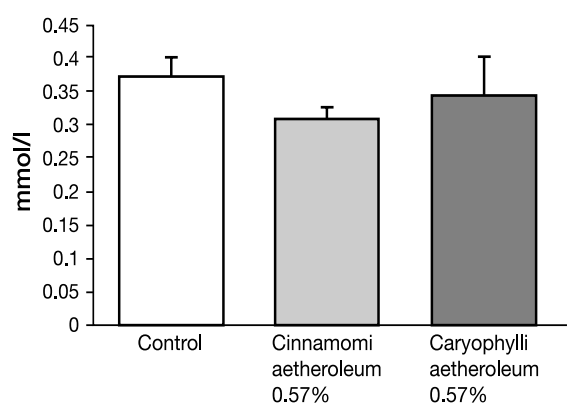

Fig. 2. Total antioxidant status of blood in mice. Each value represents the mean \pm S.E.M; $\mathrm{n}=10(* P<0.05, * * * P<$ $0.001)$

Caryophylli aetheroleum had no effect on total antioxidant status. Our findings show evidence of an increased sensitivity to oxidative stress at high dose intake of some vegetable extracts. The intake of medicinal plants in rats results in an increase in antioxidant enzyme activity and a decrease in malondialdehyde, which may reduce the risk of inflammation (Choi and Hwang 2005). Hypericum perforatum and Calendula officinalis hydroalcoholic extracts showed a significant activity (Herold et al. 2003). It will be necessary to find molecules that will increase directly or indirectly the level of antioxidant system. Our results show that essential oils affected oxidative stress in organism and they have positive and negative effect on antioxidant status. In diabetic rats treated with the ethanolic extract, a significant increase in activity of antioxidant enzymes was observed. This might reflect the antioxidant potency of the ethanolic extract, which by reducing blood glucose levels prevented 
glycation and inactivation of enzymes (Rajasekaran et al. 2005). Similar kinds of effect, i.e. prevention of potential glycation of antioxidant enzymes and the ensuing decrease in activity, have been reported with other plants, such as Eugenia jambolana, well-known for their antidiabetic activity (Ravi et al. 2004).

As Table 1 shows, body weights were significantly lower in 14 day of $1 \%$ Origani aetheroleum intake $(23.41 \pm 0.5$ vs $27.85 \pm 0.4 \mathrm{~g}, P<0.001)$ and 7 day of $1 \%$ Thymi aetheroleum intake $(17.4 \pm 0.5$ vs $21.08 \pm 0.4 \mathrm{~g}, P<0.05)$. A similar rise in body weight was observed in control and experimental groups of mice with age. Youdim and Deans (1999) show, that increase in body weight of control rats did not differ significantly from that of thyme oil treated rats except at 22 months of age, where control body weights were found to be significantly higher.

A number of previous reports suggest that cellular antioxidants are under homeostatic control and that dietary antioxidant supplementation depresses endogenous antioxidant synthesis so as to nullify the expected beneficial effect of the supplement (Barja de Quiroga et al. 1992; Bunker 1992; Warner 1992).

The oral administration of low doses to mice reduces oxidative stress induced by higher levels of antioxidant enzymes in the plasma. Thus, it appears that these spices exert antioxidant protection through their ability to activate the antioxidant enzymes.

Table 1. Body weight $(\mathrm{g})$ of mice during essential oils intake by diet. Each value represents the mean \pm S.E.M.

\begin{tabular}{|c|c|c|c|c|c|}
\hline & & \multicolumn{3}{|c|}{ Origanum vulgare } & \multirow[b]{2}{*}{$0.1 \%$} \\
\hline & Control & $1 \%$ & $0.57 \%$ & $0.25 \%$ & \\
\hline 0 -day & $20.28 \pm 0.20$ & $22.21 \pm 0.25$ & $19.49 \pm 0.53$ & $21.73 \pm 0.86$ & $20.83 \pm 0.35$ \\
\hline 7-day & $25.25 \pm 0.31$ & $23.70 \pm 0.40$ & $22.68 \pm 0.51$ & $25.26 \pm 0.31$ & $24.94 \pm 0.25$ \\
\hline 14-day & $27.85 \pm 0.43$ & $23.41 \pm 0.50^{* * * *}$ & $25.33 \pm 0.77$ & $27.99 \pm 0.45$ & $27.65 \pm 0.41$ \\
\hline 20-day & $30.41 \pm 0.47$ & $27.81 \pm 1.25$ & $27.95 \pm 0.85$ & $29.58 \pm 0.62$ & $29.19 \pm 0.46$ \\
\hline \multicolumn{6}{|c|}{ Thymi aetheroleum } \\
\hline 0 -day & $13.05 \pm 0.69$ & $12.73 \pm 0.88$ & & $13.18 \pm 0.96$ & $12.91 \pm 0.99$ \\
\hline 7-day & $21.08 \pm 0.43$ & $17.14 \pm 0.48^{*}$ & & $21.34 \pm 0.90$ & $20.84 \pm 1.05$ \\
\hline 14-day & $24.16 \pm 0.62$ & $22.15 \pm 0.58$ & & $24.24 \pm 0.63$ & $24.76 \pm 0.74$ \\
\hline \multirow[t]{3}{*}{ 20-day } & $27.01 \pm 0.72$ & $25.29 \pm 0.66$ & & $28.40 \pm 0.73$ & $28.34 \pm 0.75$ \\
\hline & \multicolumn{2}{|c|}{ Cinnamomi aetheroleum } & \multicolumn{3}{|c|}{ Caryopilli aetheroleum } \\
\hline & Control & $0.57 \%$ & & $0.57 \%$ & \\
\hline 0 -day & $13.42 \pm 1.28$ & $14.93 \pm 0.97$ & & $13.61 \pm 1.01$ & \\
\hline 7-day & $20.58 \pm 1.26$ & $21.37 \pm 0.95$ & & $19.68 \pm 1.07$ & \\
\hline 14-day & $25.02 \pm 0.92$ & $25.84 \pm 0.67$ & & $25.13 \pm 0.69$ & \\
\hline 20-day & $27.44 \pm 0.79$ & $28.89 \pm 0.71$ & & $28.31 \pm 0.49$ & \\
\hline
\end{tabular}

$\mathrm{n}=10 .(* P<0.05 ; * * * P<0.001)$

\section{Vplyv éterickych olejov na zmeny antioxidačného statusu v plazme myší}

Ciel'om práce bolo stanovit' vplyv štyroch éterických olejov Origanum vulgare, Thymus vulgaris, Cinnamomum zeylanicum Ness a Syzygium aromaticum na antioxidačný status myší in vivo. Éterické oleje boli rozpustené v etanole a primiešané do krmiva (pomleté pelety základného krmiva pre myši) v koncentráciách $0,1,0,25,0,57$ a $1 \%$. Následne bol etanol z krmiva odparený. V erytrocytoch a plazme sme merali aktivity SOD, GPx a TAS spektrofotometricky Ransod, Ransel a TAS kitmi firmy Randox. GPx bola signifikantne vyššia pri 0,25 a $0,1 \%$ koncentrácii Origanum vulgare oproti kontrole. Aktivita GPx sa znížila pri 0,1\% koncentrácii Thymus vulgaris, 0,57\% koncentrácii Cinnamomum zeylanicum Ness a 0,57\% koncentrácii Syzygium aromaticum. Celkový antioxidačný status $\mathrm{v}$ plazme bol signifikantne znížený pri 1\% koncentrácií a signifikantne zvýšený pri 
$0,1 \%$ koncentrácii Origanum vulgare. Podobné výsledky sme zistili pri Thymus vulgaris, Cinnamomum zeylanicum Ness a Syzygium aromaticum, u ktorých nebol zistený vplyv na celkový antioxidačný status v plazme. Aktivita SOD nebola zmenená po príjme éterických olejov diétou. Záverom, naše výsledky ukazujú, že koncentrácia éterických olejov prijatých krmivom je vel'mi dôležitá pre antioxidačný status organizmu a pre metabolizmus myší. Vysoká dávka éterických olejov má nepriaznivý vplyv na metabolizmus myší, predstavujúc znížený nárast telesnej hmotnosti. Na druhej strane, éterické oleje majú v nízkych dávkach pozitívny vplyv na antioxidačný status myší.

\section{Acknowledgements}

This work was supported by Science and Technology Assistance Agency under the contract No. APVT-51015404 and by the State Program of Science and Development (SP 51/028 09 00/028 09 06) and by the Grant Agency for Science VEGA No. 1/2443/05, 2/7046/27. We are grateful to Zuzana Makarová for her excellent technical assistance.

\section{References}

BARJA DE QUIROGA G, LÓPEZ-TORES M, PÉREZ-CAMPO R 1992: Relationship between antioxidants, lipid peroxidation and aging. In: EMERIT I, CHANCE B (Eds): Free radicals and aging. Birkhauser Verlag, Basel, Switzerland. pp. 109-124

BUNKER V 1992: Free radicals, antioxidants and ageing. J Lab Sci 49: 299-312

BRUCE A, FREEMAN D, JAMES C 1982: Biology of disease free radicals and tissue injury. Lab Invest 47: $412-426$

FAIX Š, FAIXOVÁ Z, BOLDIŽÁROVÁ K, JAVORSKÝ P 2005: The effect of long-term high heavy metal intake on lipid peroxidation of gastrointestinal tissue in sheep. Vet Med-Czech 50: 401-405

HEROLD A, CREMER L, CALUGARU A, TAMAS V, IONESCU F, MANEA S, SZEGLI G 2003: Antioxidant properties of some hydroalcoholic plant extracts with antiinflammatory activity. Roum Arch Microbiol Immunol 62: 217-227

HODGSON EK, FRIDOVICH I 1975: The interaction of bovine erythrocyte superoxide dismutase with hydrogen peroxide: inactivation of the enzyme. Biochemistry 24: 5294-5299

HOROSOVÁ K, BUJŇÁKOVÁ D, KMEŤ V 2004: Antimicrobial effects of essential oils on E.coli from post weaning diarrhoea. Slovenský veterinársky časopis 29: 39-40

HSU DZ, LIU MY 2004a: Effects of sesame oil on oxidative stress after the onset of sepsis in rats. Shock 22: $582-585$

HSU DZ, LIU MY 2004b: Sesame oil protects against lipopolysaccharide-stimulated oxidative stress in rats. Crit Care Med 32: 227-231

CHOIEM, HWANG JK 2005: Effect of some medicinal plants on plasma antioxidant system and lipid levels in rats. Phytoter Res 19: 382-386

MADSEN HL, BERTELSEN G 1995: Spices as antioxidants. Trends in Food Science and Technology 6: 271-277

MASELLA R, VARI R, D' ARCHIVIO M, DI BENEDETTO R, MATARRESE P, MALORNI W, SCAZZOCCHIO B, GIOVANNINI C 2004: Extra virgin olive oil biophenols inhibit cell-mediated oxidation of LDL by increasing the mRNA transcription of glutathione-related enzymes. J Nutr 134: 785-791

MCCROD JM, KEELE BB, FRIDOVICH I 1976: An enzyme based theory of obligate anaerobiosis; the physiological functions of superoxide dismutase. Proc Natl Acad Sci USA 68: 1024-1027

RAJASEKARAN S, SIVAGNANAM K, SUBRAMANIAN S 2005: Antioxidant effect of Aloe vera gel extract in streptozocin-induced diabetes in rats. Pharmacol Reports 57: 90-96

RAVI K, RAMACHANDRAN B, SUBRAMANIAN S 2004: Protective effects of Eugenia jambolana seed kernel on tissue antioxidants in streptozotocin-induced diabetic rats. Biol Pharm Bull 27: 1212-1217

SACCHETTI G, MAIETTI S, MUZZOLI M, SCAGLIANTY M, MANFREDINI S, RADICE M, BRUNI R 2005: Comparative evaluation of 11 essential oils of different origin as functional antioxidants, antiradicals and antimicrobials in foods. Food Chemistry 91: 621-632

SAWAMURA M 2000: Aroma and functional properties of Japanese yuzu (Citrus junos Tanaka) essential oil. Aroma Research 1: 14-19

WARNER HRJR 1992: Overview: mechanisms of antioxidant action on life span. In: SIES H, ERDMAN JJR, BAKER G, HENRY C, WILLIAMS G (Eds): Chemical, Physiological, Nutritional and Toxicological Aspects. Princeton Scientific Publishing, Princeton, NJ, pp. 151-160

YOUDIM KA, DEANS SG 1999: Dietary supplementation of thyme (Thymus vulgaris L.) essential oil during the lifetime of the rat: its effects on the antioxidant status in liver, kidney and heart tissues. Mechanisms of Ageing and Development 109: 163-175 